\title{
Cleidocranial dysplasia: Etiology, clinicoradiological presentation and management
}

\author{
Kleidokranial displazi: Etiyoloji, klinikoradyolojik görüntüleme ve tedavi
}

\author{
İsmet Rezani Toptancı ${ }^{1}$, Hakan Çolak ${ }^{2}$, Serhat Köseoğlu ${ }^{3}$ \\ ${ }^{1}$ Dicle University, Dental Faculty, Department of Pedodontics, Diyarbakır, Turkey \\ ${ }^{2}$ Kırıkkale University Dental Faculty, Department of Operative Dentistry, Kırıkkale, Turkey \\ ${ }^{3}$ Kırıkkale University Dental Faculty, Department of Periodontology, Kırıkkale, Turkey
}

\begin{abstract}
Cleidocranial dysplasia (CCD) is an autosomal dominant skeletal dysplasia characterised by abnormal clavicles, patent sutures and fontanelles, supernumerary teeth, short stature, and a variety of other skeletal change. Cleidocranial dysplasia is caused by mutation in the gene on 6p21 encoding transcription factor CBFA1, i.e. runtrelated transcription factor 2 (RUNX2). Individuals with CCD should be followed by either a team of specialist or by individual specialist familiar with the problems that can be associated with this condition. J Clin Exp Invest 2012; 3(1): 133-136
\end{abstract}

Key words: Cledio-cranial dysplasia, supernumerary teeth, diagnosis

\section{INTRODUCTION}

Cleidocranial Dysplasia (CCD) is a rare congenital disorder of bone with an autosomal dominant hereditary mode of inheritance with complete penetrance, but variable expressivity. This condition is characterized by clavicular aplasia or deficient formation of the clavicles, delayed and imperfect ossification of the cranium, moderately short stature, and a variety of other skeletal abnormalities. The principal oral manifestations are a delayed exfoliation of primary teeth, delayed or multiple impactions of the permanent dentition, and multiple impacted supernumerary teeth. ${ }^{1}$

Cleidocranial dysplasia was first described in a patient with congenital absence of clavicle in 1765 by Martin. ${ }^{2}$ Marie and Sainton coined the term cleidocranial dysostosis in 1898, although descriptions of the disorder can be traced back to the 1760s. ${ }^{3}$ The term dysostosis means defective ossification or defect in the normal ossification of fetal cartilages (Gr. osteon - bone). In dysostoses the distribution follows a defect in ectodermal or mesenchymal

\section{ÖZET}

Kleidokranial displazi anormal klavikula, genişlemiş suturlar ve fontaneller, süpernumeral dişler, kısa boy ve diger bir çok iskeletsel değişiklikle karakterize otozomal dominant iskeletsel displazidir. Kleidokranial displazi, gen 6 p21 genindeki şifreleme çevirme faktörü CBFA1 ve runtrelated transcription factor 2 (RUNX2) de meydana gelen mutasyonlardan kaynaklanır. Kleidokranial displazi tek başına bir uzman ekibi tarafından izlenmeli veya sorunları bilen bir uzman tarafından takip edilmelidir.

Anahtar kelimeler: Kledio-kranial displazi, artı dişler, tanı

tissues. Rarely are all bones involved. As derived from the Greek, dysplasia refers to abnormality of development or "ill formed" (Gr. plassein - to form); in pathology it means alteration in size, shape, and organization of adult cells.

The prevalence of cleidocranial dysplasia is one per million with complete penetrance and variable expressivity, but it is most likely under diagnosed because of the relative lack of medical complications in comparison with other skeletal dysplasia's. It may be discovered at any age, but the cranial deficiencies may be noticed at birth. Both sexes are affected to an approximately equal extent. The defect often appears in several successive generations. ${ }^{4}$

\section{Etiology}

The etiology though not completely known is thought to be due to a CBFA1 (core binding factor activity 1 ) gene defect on the short arm of chromosome $6 \mathrm{p} 21$ $(5,8)$. CBFA1 is essential for differentiation of stem cells into osteoblasts, so any defect in this gene will cause defects in the membraneous and endochon- 
dral bone formation..$^{8,9}$ It affects bones of intramembranous origin and endochondral bone formation of long bones, there is also failure of midline ossification. Involvement of non-membranous bones is also well recognized. ${ }^{8,10}$ Keats $^{11}$ in 1967 reported the involvement of long bones, the spine and the base of the skull. Subsequently Jarvis and Keats ${ }^{10}$ extensively reviewed the skeletal anomalies in CCD.

According to Yoshida et al. Cleidocranial dysplasia could result from a much smaller loss in the RUNX2 function. They also implied that an inherent mechanistic commonality exists between the skeletal growth and the dental development in their dependencies on the RUNX2 activity, despite the tremendous apparent dissimilarities of these two organogenesis processes. If the type of mutation in RUNX2 is known in advance, we could predict the supernumerary teeth for an individual to allow the early initiation of the necessary treatment. ${ }^{12}$

\section{Clinical features}

People with CCD have a characteristic facial appearance. They tend to have a short head from front to back (brachcephaly) and a prominent forehead (frontal bossing). There is typically delayed closure of fontanels, and some adults with CCD have open fontanels. The eyes are widely spaced, and the nasal bridge is often flat. The neck appears long, and the shoulders are narrow and down-sloping

Characteristically, patients with cleidocranial dysplasia, show prolonged retention of deciduous dentition and delayed eruption of permanent teeth. Adults with cleidocranial dysplasia have mixed dentition in their oral cavities. In addition, patients with this condition, frequently show a large number of unerupted supernumerary teeth, often mimicking a premolar. As many as 63 unerupted supernumerary teeth have been documented in one patient. ${ }^{13}$ Reason for the formation of multiple supernumerary teeth is still unknown. Maxilla is also underdeveloped along with ill-formed paranasal sinuses. Skeletal Class III tendency / mandibular prognathism in CCD can be attributed to its uninterfered growth due to hypoplastic maxilla and upward and forward mandibular rotation. ${ }^{14}$ This condition is of clinical significance to every dentist due to the involvement of the facial bones, altered eruption patterns and multiple supernumerary teeth. ${ }^{4}$

The most characteristic and pathognomic skeletal feature is that one or both clavicles are frequently partially or in $10 \%$ cases completely absent. ${ }^{15,16}$ Usually rudimentary sternal and acromial stubs are present and the mid-clavicular position is absent. Clavicular deformity along with the dysplas- tic muscle attachments give rise to elongated neck, narrow drooping and hypermobility of shoulders with tendency to approximate shoulders anteriorly. ${ }^{16}$ Clavicle is the first bone to be ossified in the 6th week of fetal life and is thus the most often affected bone. ${ }^{16}$

Incomplete ossification of contours of embryonic vertebral arches account for various vertebral deformities like spina bifida, kyphosis, scoliosis, hemivertebra and cervical ribs. Patients with cleidocranial dysostosis and progressive scoliosis should have CT scan and MRI scan to rule out the presence of syringomyelia. ${ }^{15}$

\section{Radiological findings}

The radiological appearance of CCD is almost sufficient for diagnosis. Various features that are evident on panoramic radiographs are multiple unerupted abnormal teeth, a narrow ascending ramus, a slender and pointed coronoid process, a thin zygomatic arch with a severe downward tilt, small or absent maxillary sinuses, coarse trabeculation of the mandible, cyst formation with supernumerary teeth mainly in the premolar region, and increases density of the alveolar crestal bone over unerupted teeth. ${ }^{17}$ Skull radiographs show brachycephaly, a persistently open anterior fontanelle, multiple wormian bones, open skull sutures, small sphenoid bones, and calvarial thickening especially over the occiput and wormian bones. This radiography shows a narrow thorax, oblique ribs and absence of clavicle..$^{18,19}$

\section{Differential Diagnosis}

The differential diagnosis of CCD includes craneHeise syndrome, mandibulaacral dysplaxiz, pycnodysostosis, yunis varon sydrome, CDAGS syndrome and hypophosphtasia etc. ${ }^{20}$ These conditions may share some characteristics with CCD, however all these are autosomal recessive disorders and have other specific features. Some of these conditions may result from mutation in genes that affect the action of RUNX2 on its downstream targets. ${ }^{21}$

\section{Management}

In terms of dental management of CCD, several approaches have been reported over the years. The option of no treatment was common in the past. ${ }^{22}$ Eventuation followed by provision of dentures has also been suggested. ${ }^{23}$ Some regard this approach as too invasive, especially considering the extensive bone loss experienced after removal of teeth in a patient already deficient in alveolar bone. Pusey and Durie. ${ }^{24}$ suggested removal of only the erupted 
teeth and use of a removable prosthesis to minimize alveolar bone loss. However, subsequent eruption of retained teeth can require further surgery and modification of the prosthesis. ${ }^{22}$

Early identification of the syndrome permits the planning of dental treatment by selecting the teeth that should be removed. Sato ${ }^{23}$ suggests the use of a three-dimensional method of locating the position of impacted supernumerary teeth, insisting upon the importance of the removal of the supernumerary teeth and the planning of an orthodontic treatment that will allow for occlusion of the retained teeth. Davies $^{26}$ recommends a method where orthodontic forces may be applied to un-erupted permanent teeth moving them into a satisfactory, functional and aesthetic position. Occasionally, when the teeth fail to erupt after the removal of supernumerary teeth and orthodontic traction, a combination of orthodontic-prosthodontic treatments is necessary. ${ }^{27,29}$

If bone density is below normal, treatment with calcium and vitamin $D$ supplementation should be considered. Preventive treatment for osteoporosis should be initiated at a young age since peak bone mineral density is achieved in the second and third decade. So, early diagnosis of CCD is beneficial for prompt intervention which will greatly influence the better restoration of craniofacial aesthetics and function. ${ }^{30}$

Individuals with CCD should be followed by either a team of specialist or by individual specialist familiar with the problems that can be associated with this condition. ${ }^{9}$ In young children with CCD, the fontanels may be so large as to warrant the wearing of a helmet to protect the brain. Hearing tests should be performed at birth and regularly (at least yearly) thereafter ${ }^{27}$ Affected infants should receive their firs dental evaluation by one year of age, preferably by a dentist who treats children with complex problems. Of note, it has been shown that extraction of primary teeth does not hasten the eruption of permanent teeth in this condition. Children with CCD may have recurrent otitis media (middle ear infection) related to abnormal formation of palate and/ or Eustachian tube dysfunction; this may necessitate the placement of tympanostomy tubes..$^{14,15}$ Individuals with CCD are more likely to have upper airway obstruction, and sleep habits must be carefully monitored. Regular snoring and (or restless sleep may warrant a sleep study. Occasionally, an affected individual may have a narrow crest that causes respiratory disease.$^{25}$ Finally, it is important to note that people with CCD are expected to be shorter than their typical peers and family members.
With proper anticipatory guidance, people with CCD usually lead healthy and productive lives.

\section{REFERENCES}

1. Golan I, Baumert U, Wagener $\mathrm{H}$, et al. Craniofac Res 2002; 5 (4): 243-9.

2. Martin S. Sur underpacement natural de la clavicle. J Med Chir Pharmacol 1765; 23(3): 456.

3. Marie P, Sainton P. Sur La dysostose cleidocranienne hereditaire. Rev Neurol 1898;6: 835.

4. Garg RK, Agrawal P. Clinical spectrum of cleidocranial dysplasia: a case report. Cases J 2008;1 (1):377.

5. Chelvan HT, Malathi N, Kailasam V, Ponnudurai A. Cleidocranial dysplasia: a family report. J Indian Soc Pedod Prev Dent 2009; 27 (4):249-52.

6. Cooper SC, Flaitz CM, Johnston DA, Lee B, Hecht JT. A natural history of cleidocranial dysplasia. Am J Med Genet 2001;104 (1):1-6.

7. Gulati S, Kabra M. Cleidocranial dysplasia. J Postgrad Med 2001; 47(3):204-5.

8. Mundlos S: Cleidocranial dysplasia: clinical and molecular genetics. J Med Genet 1999; 36 (3):177-82.

9. Currall V, Clancy R, Diamond D. Cleidocranial dysplasia. Curr Orthop 2007; 21 (2):159-62.

10. Jarvis JL, Keats TE. Cleidocranial dysostosis. A review of 40 new cases. Am J Roentgenol Radium Ther Nucl Med 1974; 121 (1):5-16.

11. Keats TE: Cleidocranial dysostosis: some atypical roentgen manifestations. Am J Roentgenol Radium Ther Nucl Med 1967; 100 (1):71-4.

12. Counts AL, Rohrer MD, Prasad H, Bolen P. An assessment of root cementum in cleidocranial dysplasia. Angle Orthod 2001; 71(4):293-8.

13. Yamamoto $H$, Sakae T, Davies JE. Cleidocranial dysplasia: a light microscope, electron microscope, and crystallographic study. Oral Surg Oral Med Oral Pathol 1989; 68 (2):195-200.

14. Becker A, Bimstein E, Shteyer A. Interdisciplinary treatment of multiple unerupted supernumerary teeth. Report of a case. Am J Orthod 1982; 81 (5):417-22.

15. Dore DD, MacEwen GD, Boulos MI. Cleidocranial dysostosis and syringomyelia. Review of the literature and case report. Clin Orthop Relat Res 1987; (214):229-34.

16. Nebgen D, Wood RS, Shapiro RD. Management of a mandibular fracture in a patient with cleidocranial dysplasia: report of a case and review of the literature. J Oral Maxillofac Surg 1991; 49 (4):405-9.

17. McNamara CM, O'Riordan BC, Blake M, Sandy JR. Cleidocranial dysplasia: radiological appearances on dental panoramic radiography. Dentomaxillofac Radiol 1999; 28(2):89-97.

18. Mohan RP, Suma GN, Vashishth S, Goel S. Cleidocranial dysplasia: clinico-radiological illustration of a rare case. J Oral Sci 2010, 52 (1):161-6. 
19. Tanaka JL, Ono E, Filho EM, Castilho JC, Moraes LC, Moraes ME. Cleidocranial dysplasia: importance of radiographic images in diagnosis of the condition. $J$ Oral Sci 2006; 48 (3):161-6.

20. Dixit R, Dixit K, Paramez AR. Cleidocranial dysplasia. Lung India 2010; 27 (3):176-7.

21. Goto T, Aramaki M, Yoshihashi H, et al. Large fontanelles are a shared feature of haploinsufficiency of RUNX2 and its co-activator CBFB. Congenit Anom (Kyoto) 2004: 44(4):225-9.

22. Becker A. The orthodontic treatment of impacted teeth. London: Martin Dunitz Ltd; 1998;229-323.

23. Winter G. Dental conditions in cleidocranial dysostosis. Am J Orthod Oral Surg 1943; 29 (2):61-89.

24. Pusey RF, Durie JF. A case of cleidocranial dysostosis showing failure of eruption of teeth. Br Dent J 1943; 75 (1):11-3.

25. Sato K, Sugawara J, Mitani H, Kawamura H. Use of selectively colored stereolithography for diagnosis of impacted supernumerary teeth for a patient with cleidocranial dysplasia. Int J Adult Orthodon Orthognath Surg 1998; 13(2):163-7.

26. Davies TM, Lewis DH, Gillbe GV. The surgical and orthodontic management of unerupted teeth in cleidocranial dysostosis. Br J Orthod 1987;14(1):43-7.

27. Butterworth C. Cleidocranial dysplasia: modern concepts of treatment and a report of an orthodontic resistant case requiring a restorative solution. Dent Update 1999; 26(10):458-62.

28. Gonzalez Lopez BS, Ortiz Solalinde C, Kubodera Ito T, Lara Carrillo E, Ortiz Solalinde E. Cleido cranial dysplasia: report of a family. J Oral Sci 2004; 46 (4):259-66.

29. Maw RB. Cleidocranial dysostosis: report of case. J Am Dent Assoc 1978; 96 (2):306-9.

30. Pradhuman V, Kanika GV, Som DG: Cleidocranial dysplasia: a dilemma in diagnosis? Arch Orofac Sci 2010; 5(2):61-4. 